\title{
Don't Stop the Music: An Exploration of First-Generation College Students' Use of Music During Pre-Pandemic and Pandemic Times
}

\author{
joshuah whittinghill \\ California State University \\ Norkeith E. Smith \\ California State University \\ K. Damon Aiken \\ California State University
}

\begin{abstract}
First-generation college student enrollment has increased significantly in recent years and a sizeable canon exists to help understand their journey to and through higher education, as well as subsequent persistence, retention and graduation rates. This research is the first to investigate how and why first-generation college students use music. Two studies compare usage patterns in pre-and pandemic settings. Study One (N=583) found that students listen to roughly four hours per day and that nearly $75 \%$ of students listen to music while studying. Moreover, first-generation students indicated that they listen to music more frequently and for more inward-focused coping reasons. Study Two (N=441) was an Internet survey (conducted during the pandemic) that supported and augmented many of Study One's findings. While music plays an important role for all students, it is critically important to first-generation students. Key findings illuminate what genres students listen to and eleven reasons why students listen to music, which are highlighted by identifying and expressing emotions, relieving stress, relieving stress, and increasing creativity.
\end{abstract}

Keywords: first-generation, music, study habits, academic performance

\section{INTRODUCTION}

Music is probably the one real magic I have encountered in my life. There's not some trick involved with it. It's pure and it's real. It moves, it heals, it communicates and does all these incredible things.

Tom Petty (McCormick, 2012)

Music has been an artifact among numerous cultures for centuries. There is recent evidence of flutes, made from bird bone, being used over 40,000 years ago (Higham, et al., 2012). Today, through great technological strides, music has never been more prevalent and over one trillion songs are streamed each year in the United States alone (Statista, 2020). Consumers find themselves just a click or tap away from an infinite library of listening options. As a result, college students, many of whom have had access to the 
Internet since before entering kindergarten, are confident in instantly finding myriad musical options. Some intriguing research questions arise. Why do college students listen to music? More specifically, how does music benefit students? How much music are students listening to? What types of music are they listening to? Anecdotally, why are so many students listening to music while they read, study, or do other schoolrelated projects? These issues are important and have yet to be explored in depth for first-generation college students in the United States.

Extant research reveals that music plays a significant role in the lives of college students. One study indicates that students listen to between two and nine hours of music per day (Gurgen, 2016). More profoundly, students indicate they set aside more time for listening to music than any other daily activity (Lamont, et al., 2003). Further, research shows that music impacts people's social and emotional development, namely: 1) self-awareness (e.g., identifying one's own emotions, expressing complex feelings); 2) self-management (e.g., soothing anxiety, setting and working towards goals); 3) social awareness (e.g., developing empathy, understanding social and ethical behavior); 4) relationship skills (e.g., building healthy relationships, negotiating conflict); and, 5) responsible decision making (e.g., identifying problems, evaluating consequences of choices) (Carpentier, et al., 2003; Kokotsaki \& Hallam, 2007; North et al., 2000). Music plays key roles in the academic, personal and social lives of young adults, even across various cultures (Lamont et al., 2003; North et al., 2004; Saarikallio \& Erkkilä, 2007). Lastly, past works suggest that music impacts both academic achievement and social success in higher education (Serrano, 2015; Tarrant et al., 2000; Tekman \& Hortac, 2002).

To date, all of the studies investigating college students' music consumption are focused on the general population of students and are not specific to first-generation students. Thus, the purpose of the current work is to examine first-generation college students' usage of music and the related connections to their study habits, motivations, and academic performance. Two large-scale surveys attempt to capture big enough sample sizes to make comparisons between first-generation and non-first-generation students. As this work is foundational and exploratory, we make no formal hypotheses. However, the work concludes with a discussion of key points, implications, and future studies.

\section{CONCEPTUAL BACKGROUND}

\section{First-Generation College Students}

The times they are a changin'

(Dylan, 1964).

Music can change the world because it can change people.

Bono (US Music Festival, 1983)

Over the past forty years, access to higher education for first-generation, low-income students of color has dramatically increased. First-generation students are defined as those whose parents have no education beyond high school, or may have some college, postsecondary certificates, or associate's degrees, but no bachelor's degrees (USDoE, 1998; UC, 2017).

Unfortunately, disparities in retention, engagement and graduation are prevalent across the country (McCarron \& Inkelas, 2006). It is important to acknowledge that a majority of first-year students who identify as underprepared students also identify as first-generation and come from low-income families and communities of color (Melzer \& Grant, 2016). The literature emphasizes that underprepared students have a more developed external locus of control and, compared to prepared students, have less confidence in their decision-making abilities and reach out to faculty less often (Pascarella et. al., 2004).

First-generation enrollments in higher education represent a significant trend. Four-year universities are seeing one in every six students is a first-generation student, and including community colleges raises this statistic to an astounding one in every three students (Ward, et. al., 2012). Subsequently there has been, and continues to be, a significant amount of research on understanding these students' journeys to and 
experiences in higher education. In light of the long-standing ideals, beliefs and deeply embedded hierarchies present on college campuses, first-generation college students encounter barriers which result in negative academic experiences and diminished outcomes (Cataldi, et al., 2018; Jenkins, et al., 2013; McCarron \& Inkelas, 2006; Pratt, et al., 2017).

W.E.B. Dubois (1903) addressed the reality of inequality in the U.S. with his reflection, "To be a poor man is hard, but to be a poor race in a land of dollars is the very bottom of hardships." (p. 4). Graduation rates and degree attainments have staggering effects in relation to self-esteem, unemployment, long-term health, use of public assistance and potential career earnings (Drago, 2008; Ellis \& Taylor, 1983). A substantial amount of research has been carried out to better understand persistence, retention and graduation especially for underrepresented populations. Key findings indicate that what happens out of the classroom and off campus may greatly impact academic experiences as significantly as what happens on campus and in classrooms (Braxton, et al., 2000; Kuh, 1995; Tinto, 1987). We also know that out-of-class experiences play significant roles in nurturing students' understanding and sense making of their development both as students and people (CASEL, 2018; Degand, 2015; Engle \& Tinto, 2008; Kuh, et. al., 2008; Wyatt \& Bloemker, 2013). Literature provides findings that Social and Emotional Learning can enrich student development, increase student achievement and enhance career experiences after graduation (Coryn, 2009).

A sizeable canon exists to help understand first-generation college students. Yet, there is a significant gap in literature about first-generation college students' relationships with music and academic achievement. Ultimately there are significant differences (pre-college characteristics, academic engagement and outcomes as well as social and emotional competencies) between first-generation and nonfirst-generation college students (Zwerling \& London, 1992). How first-generation students come to understand and make sense of their positions within education is influenced by myriad social and/or familial variables which include, but are not limited to - cultural traditions, language, family, religion, spirituality, gender, sexual orientation, age, previous academic experiences, marginalized cultural experiences and biased socioeconomic experiences (Rendon, 1994; Pascarella, et. al., 2004; Terenzini, et. al., 1996; Ward, et. al, 2012). These characteristics and experiences imply first-generation students often engage with education from the margins and remain peripheral to their own experiences. For many students, education is filled with antiquated activities, traditional texts and curriculum lacking in diversity, all of which continue to invalidate students.

In addition, Laura Rendon (1994) suggests more subtle forms of support must accompany traditional efforts. She identifies new approaches as validating experiences. Validating students would include increased encounters with administrators, faculty who express to first-generation students that they are competent learners, that they can succeed, that they are essential to creating academic community and that their lived experiences, family and culture are sources of knowledge, skills and abilities. And as a result, should never be devalued as stated in Serrano's (2015) work addressing the importance Ska music plays for the ChicanX LatinX subcultures. Serrano highlights Ska music's ability to raise awareness about issues ranging from inequalities in education, to immigration, police brutality and access to resources, while also validating and celebrating cultural heritage and national pride.

\section{Music in Education}

\section{It isn't where you came from, it's where you're going that counts.}

Ella Fitzgerald (Peacock \& Sydral, 2021)

While fulfilling various roles (mood control, sense of belonging, validation, inspiration, etc.), music has long been central to human existence (Schäfer, et al., 2013; Gabrielson \& Juslin, 1996; Zillmann, et al., 1997). Music conveys a variety of messages including hope, positivity, despair, anger, outrage, validation and love (North et al., 2000). Still, research reveals that people's age, country of origin, language and overall cultural beliefs may hinder them from identifying messages, anecdotes or stories in song (Mehr, et al., 2017; Walker, 1996). Despite cross-cultural barriers in identifying the specifics of music, anthropologists, 
ethnomusicologists and cognitive scientists alike echo the sentiments of Alan Merriam that, "there is probably no other human cultural activity which is so all-pervasive and which reaches into, shapes and often controls so much of human behavior" (1964, p. 218).

Research indicates a connection exists between music and social and emotional development. Music can be instrumental in regulating emotions, facilitating social acceptance, developing and validating selfidentity, as well as enhancing cognitive learning (Gurgen, 2016; Hargreaves \& North, 1999; Matsunobu, 2011; Merriam et al., 1964; Saarikallio \& Erkkilä, 2007). Similarly, evidence shows positive relationships between social and emotional competencies and increased self-esteem, and social awareness as well as positive academic and labor market outcomes (Chemers, et al., 2001; Elias, 2006; Ippolito \& Adler, 2018).

For centuries, educators have focused on transferring knowledge to students. As a result, curricula have often neglected study skills and work habits as well as social and emotional development - all factors which enhance student achievement, enrich relationships with faculty, encourage community involvement, and assist with professional development (Elias, 2006; Wang, et al., 2012). However, education as a system is shifting, and research indicates that re-designed social and emotional curricula can be the bridge between intended knowledge to be learned and educational and professional success (Borghans et al., 2008; Hart, 2018; Heckman, et al., 2006).

Ultimately, whether one is a producer (musician) or a consumer (listener) of music, their engagement and response to a piece of music will be informed by the interaction between the characteristics of the person (e.g. age, race, ethnicity, cultural background, religion, age, gender etc.), the nature of the music (e.g. meaning, composition or genre etc.), and the setting and situation in which the piece being heard (Hargreaves \& North, 1999; North, et. al., 2004). Evidence suggests music may do more than fulfill social dynamics or nurture social and emotional competencies. Research in the natural sciences indicates a neurobiological role between music and social bonding as well as an ability to produce physical reactions, such as sweating, sexual arousal, and even the figurative "shivers down the spine" (Freeman, 2001; Mehr, et. al., 2017).

\section{Music in University Education}

College students, especially first-generation students, experience an ecological transition, putting them in a state of liminality required to manage new settings, expectations and demands, while in chorus leaving familiar surroundings, and for many a sense of comfort or security from their support groups (Bronfenbrenner, 1979). Similarly, Tinto (1987) theorizes that college students often find it difficult to set and achieve goals, in and out of the classroom, as they face increased unfamiliar anxieties in a new and demanding academic setting. Students unable to balance their personal lives with their educations may lead to higher rates of depression, anxiety, stop-out rates, substance abuse and suicide ideation (Crutchfield \& Maguire, 2018; Hoyle \& Crawford, 1994). While music is commonly used as a tool in easing psychological stresses and diminishing social anxiety (Hargreaves \& North, 1999), relatively few researchers have explored the role music plays for students in bridging their transitions to college and enhancing their study habits, academic achievements, and social success.

Psychological research into music has evolved from initially being concentrated on cognitive and emotional functions, to more recently concerned with music's social functions (Hargreaves \& North, 1999; Manturszewska, et. al., 1995; Serrano, 2015; Tekman \& Hortac, 2002). Music can be an extremely personal experience, wherein the listener can lock themselves away and avoid social interaction. Interestingly, the exact same music can bring people together as many aspects of music are largely social by nature (Hargraves \& North, 1999). Research suggests that music may be influential for individuals as well as entire groups when it comes to social and emotional competencies, more specifically in: managing self-identity; navigating relationships; mood and impulse control; self-awareness; validation; self-confidence; empathy; appreciating and understanding the value of diversity; social engagement; identifying problems; reflection; emotional countenance and decision making. (Manturszewska, et. al., 1995; Mehr, et. al., 2017; Rentfrow \& Gosling, 2003).

In qualitative studies, students revealed that engaging with music enhances their appreciation of others, improves their social skills, increases their self-esteem as well as sense of identity and is ultimately 
therapeutic (Lamont, et al, 2003). However, little research has specifically examined the impact of music on college students' study habits, academic achievement, or social and emotional competencies. Meanwhile a review of the literature on adult participation in music reveals similar benefits reported and can be organized as follows: "(1) personal motivations, such as self-expression, recreation, self-improvement, and use of leisure time; (2) musical motivations, such as professed love of music, performing for oneself and others, learning more about music; and (3) social motivations (meeting new people, being with friends, and having a sense of belonging" (Coffman, 2009). Sir Ken Robinson posited, in a 2001 report on the state of the arts, that weaving music into curricula cultivates opportunities for students to express themselves, develop cross-cutting skills (especially those associated with creativity and critical thinking), and enhance emotional intelligence (Robinson, 2001). Students inabilities to identify and feelings can lead to personal, social and academic deficits, all of which can be offset with the use of music (Robinson, 2001).

As a cultural activity, music is a transformative artifact supporting various identities and experiences (e.g. race, ethnicity, gender identities, sexual orientations, etc.) as well as social and emotional competencies including self-confidence, stress management, self-motivation, relationship building and empathy (Herbert, 2012; North, et. al., 2000; North, et. al., 2004; Serrano, 2015). For many college students, the transition to college is preceded by anxiety and uncertainty of academic success, which is followed by assimilation to college life, balancing time, socializing and of course studying. However, with the assistance of music as both a social emollient and a cognitive and emotional stabilizer, students can more easily have their identities validated, their transitions nurtured and their goals attained.

\section{METHODS}

\section{One good thing about music - when it hits you, you feel no pain. Bob Marley (Marley, 1975)}

\section{Study One}

The purpose of Study One was to gain a foundational understanding of how and why first-generation (and, in comparison, non-first-generation) university students use music. Respondents were recruited using a mix of convenience and judgement sampling at a mid-sized university in northern California. The university had been designated a "Hispanic-Serving Institution" with membership in the Hispanic Association of Colleges and Universities and $35.6 \%$ of students classified as Hispanic/Latino. It should be noted that California's first-generation demographic is somewhat different than much of the U.S. in that the majority of first-generation students have Mexican heritage (UCOP, 2017).

Data collection took place over a two-week period in classroom settings. The three-part, paper-andpencil survey was administered across the student population; however, certain classes were identified and included in the judgement sample because of their high numbers of first-generation students. Respondents' participation was voluntary, and aside from taking up the first 10-15 minutes of class time, no benefits were given.

Part one of the survey asked respondents to provide demographic and personal information and contained a mix of categorical and open-ended questions. In this section, students supplied data regarding their gender, ethnicity, generational standing, grade point average, and the number of hours per day spent listening to music.

Part two of the survey had two multi-part questions. First, respondents were asked what types of music they listen to in a "check all that apply" format. Eighteen genres of music were listed. Study One and Study Two yielded similar results in types of music listened to. Hip hop, rap, R\&B and unexpectedly instrumental were at the top of genres that students listen to while doing homework, studying, or reading. Second, respondents were asked about the reasons why they listen to music. From a list of 15 motivations, respondents were again asked to check all that apply (e.g., for enjoyment, to relieve boredom, to reduce loneliness). These variables were drawn from the works of Juslin, et al., 2008, Lamont, et al., 2003, and North et al., 2004. 
Part three of the survey used a multi-part measure inquiring about music usage during their studies. The survey first asked students to categorize themselves in one of three ways: 1) "I do NOT play music when I study;" 2) "I SOMETIMES play music (e.g., 'yes' when doing homework, but "no' when studying for a test);" or, 3) "I DO play music when I study" Each of the three response categories followed with adjective ratings, wherein respondents stated that they do not, sometimes, or do listen "because it makes me feel

" followed by a set of five adjectives rated on Likert scales. The adjectives for respondents in the "NOT" group were: nervous, depressed, anxious/worried, angry, and less focused. The self-categorized "SOMETIMES" and "I DO" groups rated the adjectives: optimistic, happy, enthusiastic, less lonely, and more focused. Surveys were collected anonymously in large, unmarked envelopes.

\section{Study Two}

The two main objectives of Study Two were to further validate the findings of Study One, and then to gain insight into how music usage amongst college students may have changed during the COVID-19 pandemic. Data collection took place over the first two weeks of April, 2021. Study Two utilized a similar three-part survey, but it was administered over the Internet. Again, a judgement sampling technique was employed to gather data from classes in the general population and simultaneously target classes known to have high numbers of first-generation students (through email solicitations, at the same California State University).

After an introduction and statement of consent, Part one of the survey asked demographic questions similar to Study One (i.e., gender, ethnicity, GPA, generational standing). However, in this instance, respondents were also asked about employment status, their daily hours spent listening to music, and an estimate of their hours spent listening pre-COVID. Part two of the survey was identical to Study One in asking about 18 genres of music in a "check all that apply" format. Part two then differed from Study One in recording the reasons why respondents listen to music. In this instance, rather than answer dichotomous questions, respondents utilized a 10-point "drag-and-drop" interval rating scale for each variable. Lastly, in parallel to Study One, part three of the Internet survey asked about music usage while studying. It followed the same format of respondents choosing a "NOT," "SOMETIMES" or "I DO" (listen while studying) path, before being asked about reasons/feelings across the same adjective scales.

\section{RESULTS}

Please don't stop the music, music, music, music.

Rhianna (Fenty, 2007)

The best music is essentially there to provide you something to face the world with. Bruce Springsteen (Anthony, 2008)

The samples of both studies captured a wide range of students representing various demographic characteristics. Study One yielded 606 responses of which 583 (96\%) were usable. Meanwhile, Study Two yielded 445 responses of which 441 (99\%) were usable. For purposes of reporting results, comparisons between the two studies are made below. 
TABLE 1

COMPARISON OF STUDY ONE AND STUDY TWO DEMOGRAPHICS



The percentages of students who identified as first-generation were not significantly different between the two studies, with first-generation students comprising 53.9\% and 56.7\% of participants in Studies 1 and 2, respectively. Similarly, the percentage of non-first-generation students remained relatively consistent between Study One (46.1\%), and Study Two (42.9\%). Across both studies, students identifying as white $(47.3 \%$ and $46.5 \%)$ and LatinX (30\% and 31.5\%) comprised the majority of the sample. Asian, AfricanAmerican/Black, and students identifying as other, or not identifying at all, comprised $10 \%$ or less of the sample in both studies. Male students comprised a greater percentage of participants in the first study $(60.5 \%)$, than the second study $(48.3 \%)$, while females participants comprised a smaller percentage of the sample in the first study (38.4\%), than the second, (50.8\%).

TABLE 2

COMPARING GPA AND MUSIC USAGE BY FIRST-GENERATION STATUS ACROSS STUDY ONE AND STUDY TWO

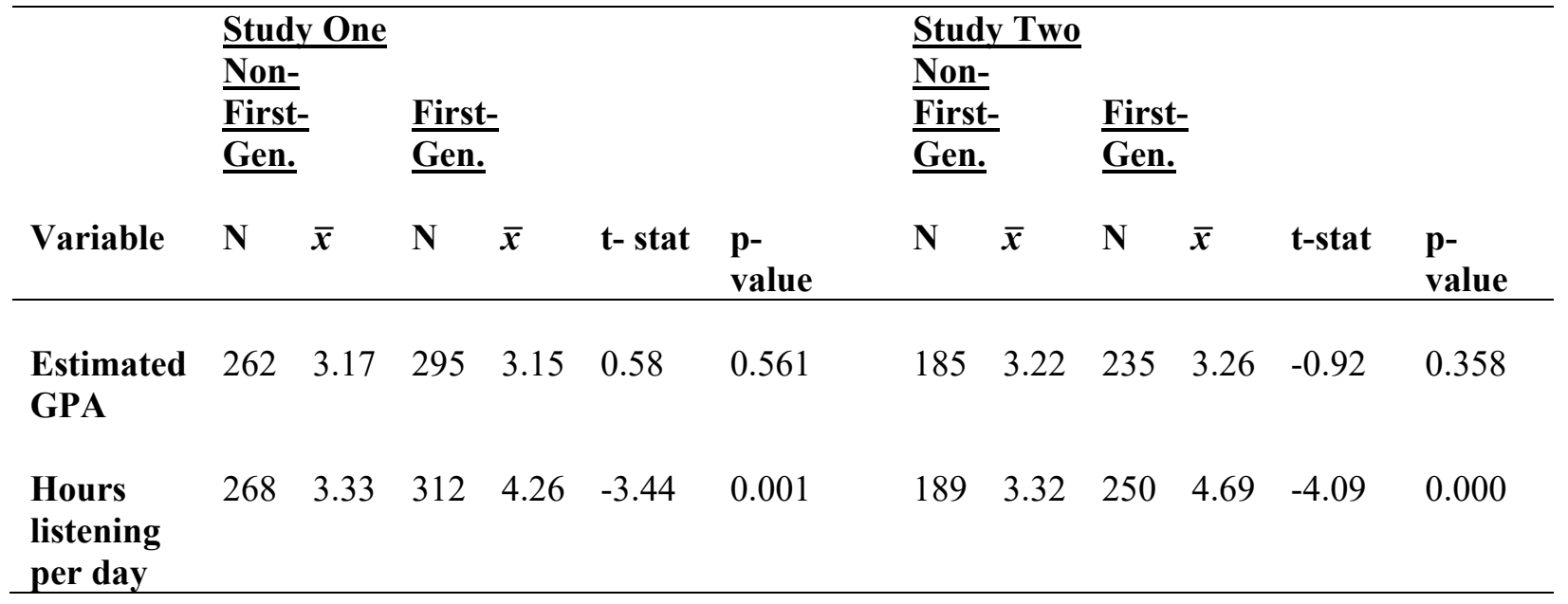


While music usage was not found to significantly impact grade point average in either study amongst non-first generation vs. first-generation students, $(\mathrm{p}=0.561, \mathrm{p}=0.358)$, the number of hours per day students listened to music was significantly different between non-first generation and first-generation students in both studies, $(\mathrm{p}<0.01$ in both instances $)$. The replicability of the results helps confirm the validity of our findings. First-generation students listen to more music than their non-first-generation counterparts (especially, during the pandemic).

Race and ethnicity emerged as important when looking at first-generation and non-first-generation students. A comparison of the cross-tabulation of student first-generation status and ethnicity between Study One and Study Two indicated distributions of ethnicity across both studies that were very similar, which indicates consistency across both samples. Furthermore, $\chi 2$ tests indicate that there was a significant relationship between ethnicity and first-generation status for Study One $(\chi 2=141.2, p<.01)$ and Study Two $(\chi 2=107.8, \mathrm{p}<.01)$. Students that identified as White were more likely to be represented in the nonfirst-generation group, whereas, students that identified as LatinX, Asian, or AA/Black students were likely to appear in the first-generation group of students (in both studies).

TABLE 3

DO YOU LISTEN TO MUSIC WHEN YOU READ, STUDY OR DO HOMEWORK BY FIRSTGENERATION STATUS COMPARISON BETWEEN STUDY ONE AND STUDY TWO

\begin{tabular}{|c|c|c|c|c|c|c|}
\hline \multirow[b]{2}{*}{$\begin{array}{l}\text { Do You Listen to } \\
\text { Music When You } \\
\text { Read, Study or } \\
\text { Do Homework? }\end{array}$} & \multicolumn{3}{|c|}{ Study One } & \multicolumn{3}{|l|}{ Study Two } \\
\hline & $\begin{array}{l}\frac{\text { Non- }}{\text { First-Gen. }} \\
\text { Count } \\
\text { (Expected } \\
\text { Count) }\end{array}$ & $\begin{array}{l}\text { First-Gen. } \\
\text { Count } \\
\text { (Expected } \\
\text { Count) }\end{array}$ & $\underline{\text { Total }}$ & $\begin{array}{l}\text { Non- } \\
\text { First-Gen. } \\
\text { Count } \\
\text { (Expected } \\
\text { Count) }\end{array}$ & $\begin{array}{l}\text { First-Gen. } \\
\text { Count } \\
\text { (Expected } \\
\text { Count) }\end{array}$ & $\underline{\text { Total }}$ \\
\hline Never & $\begin{array}{c}63 \\
(59.9)\end{array}$ & $\begin{array}{c}67 \\
(70.1)\end{array}$ & 130 & $\begin{array}{c}17 \\
(20.7)\end{array}$ & $\begin{array}{c}31 \\
(27.3)\end{array}$ & 48 \\
\hline Sometimes & $\begin{array}{c}47 \\
(62.6)\end{array}$ & $\begin{array}{c}89 \\
(73.4)\end{array}$ & 136 & $\begin{array}{c}134 \\
(117.1)\end{array}$ & $\begin{array}{c}138 \\
(154.9)\end{array}$ & 272 \\
\hline Always & $\begin{array}{c}152 \\
(139.5) \\
\end{array}$ & $\begin{array}{c}151 \\
(163.5) \\
\end{array}$ & 303 & $\begin{array}{c}38 \\
(51.2) \\
\end{array}$ & $\begin{array}{c}81 \\
(67.8) \\
\end{array}$ & 119 \\
\hline Total & 262 & 307 & 569 & 189 & 250 & 439 \\
\hline $\begin{array}{l}\text { Pearson } \chi^{2} \\
\text { (p-value) }\end{array}$ & & $\begin{array}{c}9.60 \\
(.008)\end{array}$ & & & $\begin{array}{l}11.42 \\
(.003)\end{array}$ & \\
\hline
\end{tabular}

Table 3 evaluates whether students listen to music when they read, study, or do homework by firstgeneration status for Study One and Study Two. It presents the counts and expected counts of these variables. Assessing the Never, Sometimes, and Always (listening while studying) groups in relationship to non-first-generation and first-generation groups, the results from Table 3 revealed that the variables were not independent for neither Study One $\left(\chi^{2}=9.60 ; \mathrm{p}<.01\right)$ nor Study Two $\left(\chi^{2}=11.42 ; \mathrm{p}<.01\right)$. Firstgeneration students in Study One are overrepresented in the Sometimes group, while first-generation students in the Always group are overrepresented in Study Two. There is a significant relationship between being a first-generation student and listening while studying.

Table 4 evaluates why students listen to music by their generational status by illustrating the counts and percentages of these variables. Data revealed that generational status was significantly related to multiple reasons given for listening to music. 
TABLE 4

WHY STUDENTS LISTEN BY FIRST-GENERATION STATUS*

\section{Panel A: Study One}

\begin{tabular}{|c|c|c|c|c|}
\hline$\underline{\text { Reasons }}$ & $\begin{array}{l}\frac{\text { Non- }}{\text { First-Gen }} \\
\mathrm{N}=269 \\
(\%)\end{array}$ & $\begin{array}{l}\text { First-Gen } \\
\mathrm{N}=314 \\
(\%)\end{array}$ & $\underline{X^{2}-\text { value }}$ & $\begin{array}{l}\text { Sig. } \\
\text { p-value }\end{array}$ \\
\hline To relieve tension/stress & $\begin{array}{l}196 \\
(72.8)\end{array}$ & $\begin{array}{l}251 \\
(79.9)\end{array}$ & 4.05 & 0.044 \\
\hline To help get through difficult times & $\begin{array}{l}183 \\
(68.0)\end{array}$ & $\begin{array}{l}230 \\
(73.2)\end{array}$ & & \\
\hline To relieve boredom & $\begin{array}{l}182 \\
(67.7)\end{array}$ & $\begin{array}{l}231 \\
(73.6)\end{array}$ & & \\
\hline To express feelings/emotions & $\begin{array}{l}143 \\
(53.2)\end{array}$ & $\begin{array}{l}216 \\
(68.8)\end{array}$ & 14.96 & 0.000 \\
\hline To be creative/use imagination & $\begin{array}{l}73 \\
(37.8)\end{array}$ & $\begin{array}{l}152 \\
(48.9)\end{array}$ & & \\
\hline To reduce loneliness & $\begin{array}{l}79 \\
(29.4)\end{array}$ & $\begin{array}{l}130 \\
(41.4)\end{array}$ & 9.12 & 0.003 \\
\hline To increase social interaction & $\begin{array}{l}83 \\
(30.9)\end{array}$ & $\begin{array}{l}70 \\
(22.3)\end{array}$ & 5.49 & 0.019 \\
\hline $\begin{array}{l}\text { To have experiences and/or } \\
\text { identities validated }\end{array}$ & $\begin{array}{l}58 \\
(21.6)\end{array}$ & $\begin{array}{l}57 \\
(18.2)\end{array}$ & & \\
\hline To create a self-image & $\begin{array}{l}42 \\
(15.6)\end{array}$ & $\begin{array}{l}43 \\
(7.3)\end{array}$ & & \\
\hline To please friends & $\begin{array}{l}31 \\
(11.5)\end{array}$ & $\begin{array}{l}23 \\
(10.6)\end{array}$ & & \\
\hline To be popular with others & $\begin{array}{l}26 \\
(10.0)\end{array}$ & $\begin{array}{l}17 \\
(5.4)\end{array}$ & 3.83 & 0.050 \\
\hline To be part of a group & $\begin{array}{l}33 \\
(12.3)\end{array}$ & $\begin{array}{l}16 \\
(5.1)\end{array}$ & 9.68 & 0.002 \\
\hline
\end{tabular}

* Respondents checked multiple answers.

\begin{tabular}{|c|c|c|c|c|}
\hline \multicolumn{5}{|l|}{ Panel B: Study Two* } \\
\hline$\underline{\text { Reasons }}$ & $\begin{array}{l}\text { Non- } \\
\text { First-Gen } \\
\mathrm{N}=193 \\
\operatorname{Mean}(S D)\end{array}$ & $\begin{array}{l}\text { First-Gen } \\
\mathrm{N}=311 \\
\operatorname{Mean}(S D)\end{array}$ & $\underline{t \text {-statistic }}$ & $\begin{array}{l}\text { Sig. } \\
\text { p-value }\end{array}$ \\
\hline For enjoyment & $\begin{array}{l}188 \\
9.05(1.7)\end{array}$ & $\begin{array}{l}249 \\
9.16(1.6)\end{array}$ & & \\
\hline To relieve tension/stress & $\begin{array}{l}179 \\
7.32(2.6)\end{array}$ & $\begin{array}{l}246 \\
7.90(2.5)\end{array}$ & -2.27 & 0.024 \\
\hline To help get through difficult times & $\begin{array}{l}179 \\
6.74(3.1)\end{array}$ & $\begin{array}{l}240 \\
7.64(2.8)\end{array}$ & -3.08 & 0.002 \\
\hline To relieve boredom & $\begin{array}{l}179 \\
6.35(3.1)\end{array}$ & $\begin{array}{l}244 \\
7.20(2.9)\end{array}$ & -2.88 & 0.004 \\
\hline To express feelings/emotions & $\begin{array}{l}165 \\
6.39(3.1)\end{array}$ & $\begin{array}{l}229 \\
7.33(2.8)\end{array}$ & -3.06 & 0.002 \\
\hline To be creative/use imagination & $\begin{array}{l}167 \\
5.37(3.0)\end{array}$ & $\begin{array}{l}152 \\
6.01(2.9)\end{array}$ & -2.16 & 0.032 \\
\hline
\end{tabular}




\begin{tabular}{lllll}
\hline To reduce loneliness & 145 & 204 & \\
& $4.54(3.3)$ & $5.4(3.2)$ & -2.42 & 0.016 \\
To increase social interaction & 147 & 189 & & \\
& $4.56(3.2)$ & $3.90(3.0)$ & & \\
To have experiences and/or & 133 & 183 & & \\
identities validated & $3.59(3.0)$ & $3.83(3.3)$ & -2.01 & \\
To create a self-image & 139 & 183 & & \\
& $3.19(3.1)$ & $3.91(3.3)$ & & \\
To please friends & 127 & 152 & \\
& $2.56(2.6)$ & $2.02(2.6)$ & & \\
To be popular with others & 133 & 172 & & \\
& $2.30(2.5)$ & $1.81(2.5)$ & & \\
To be part of a group & 133 & 164 & & \\
& $2.83(2.8)$ & $2.13(2.6)$ & 2.21 & \\
\hline
\end{tabular}

* Respondents checked multiple answers. Variables scored on 1-10 scale.

Panel A of Table 4 indicated that there were significant differences between reasons why firstgeneration and non-first-generation students listen to music. First, first-generation students were significantly more likely to listen to music in order to express feelings/emotions $(\chi 2=14.96 ; \mathrm{p}<0.01)$ in comparison to non-first-generation students. Additionally, first-generation students were significantly more likely to listen to music in order to reduce loneliness $(\chi 2=9.12 ; \mathrm{p}<0.01)$, and to relieve tension/stress $(\chi 2$ $=9.12 ; \mathrm{p}<0.05)$. On the contrary, first-generation students were significantly less likely to listen to music to be part of a group $(\chi 2=9.68 ; p<0.01)$, to increase social interaction $(\chi 2=5.49 ; p<0.05)$, and to be popular with others $(\chi 2=3.83 ; \mathrm{p}<0.05)$.

Next, this study revealed evidence of consistency between Study One (pre-pandemic) and Study Two (during the pandemic) by noting similarities in the likelihood of listening to music while studying by comparing the results in Panel A to those exhibited in Panel B of Table 4. Panel B of Table 4 indicated significant differences in the likelihood of listening to music while studying (using a 10-point Likert-type scale) between why first-generation and non-first-generation students. First-generation students demonstrated a significantly greater likelihood to listen to music in order to express their feelings/emotions relative to non-first-generation students $(t=-3.06 ; \mathrm{p}<0.01)$. Next, first-generation students demonstrated a higher likelihood to listen to music in order to reduce loneliness in contrast to non-first-generation students $(\mathrm{t}=-2.42 ; \mathrm{p}<0.05)$. Next, first-generation students were significantly less likely to listen to music to be part of a group compared to non-first-generation students $(\mathrm{t}=2.21 ; \mathrm{p}<0.05)$.

Further, this study identified evidence that failed to demonstrate consistency from Study One (prepandemic) and Study Two (during the pandemic) by noting key distinctions in the likelihood of listening to music while studying by noting the results that differ across Panel A and Panel B of Table 4. Firstgeneration students exhibited a greater likelihood to listen to music to help get through difficult times relative to non-first-generation students $(\mathrm{t}=-3.08 ; \mathrm{p}<0.01)$ in Study Two. Next, first-generation students were significantly more likely to listen to music in order to relieve boredom compared to non-firstgeneration students $(\mathrm{t}=-2.88 ; \mathrm{p}<0.01)$ in Study Two. First-generation students were significantly more likely to listen to music in order to relieve tension/stress in contrast to non-first-generation students $(\mathrm{t}=$ 2.27; $\mathrm{p}<0.05)$ in Study Two. In addition, first-generation students were significantly more likely to listen to music to be creative/use imagination compared to non-first-generation students $(\mathrm{t}=-2.16 ; \mathrm{p}<0.05)$. Last, first-generation students were significantly more likely to listen to music to in order create a self-image compared to non-first-generation students $(\mathrm{t}=-2.05 ; \mathrm{p}<0.05)$ in Study Two. 


\title{
CONCLUSION
}

\begin{abstract}
I think music in itself is healing. It's an explosive expression of humanity. It's something we are all touched by.
\end{abstract}

BillyJoel (Schruers, 2014)

While this work was exploratory in nature, it uncovered a number of interesting findings related to music usage in first-generation students. Taken in total, our studies revealed that music is certainly in extensive use amongst college students. Across the combined samples, a full $83.7 \%$ of students reported that they listen to music while studying $(\mathrm{N}=1,018)$. Further, the combined groups reported listening to a mean of 3.8 hours daily with a relatively low, negative correlation to self-reported GPA $(r=-.07)$. Study Two showed a pandemic-era effect on usage - increasing the mean to 4.1 hours per day. Gender identity had no relationship to music usage in terms of hours, tendency to consume while studying, nor related effects on GPA (i.e., using music while studying did not help women/men differentially). The widespread use of music may be attributed to advanced technology, increased accessibility, and the relatively low cost of music consumption for today's college students.

Some notable findings emerged with regards to first-generation students and music consumption. Firstgeneration students reported listening to significantly more music daily; however, they are not more likely to listen while studying in comparison to their non-first-generation counterparts. This may be partly due to a ceiling effect wherein the vast majority of students in this age cohort listen while studying. Interestingly, first-generation students appear to be listening to music for different reasons. That is, while first-generation students listen to relieve stresses, reduce loneliness, and express their feelings, non-first-generation students are comparatively more likely to listen in order to be popular, be part of a group, and to increase social interactions. Thus, it appears that first-generation college students use music as a personal, inward-focused, coping mechanism that helps them deal with a different set of collegiate and life circumstances.

Not surprisingly, "for enjoyment" was the most popular response across the total sample. On the other hand, "to relieve tension/stress" and "to help get through difficult times" were unexpectedly also top reasons students listened to music. Notably, female students were more likely to utilize music managing hardship and dealing with stresses compared to male students. Males appeared more likely to use music to enhance their creativity.

Across both studies and all sample sub-groups, the bottom three reasons given for listening to music ("to please friends," "to be popular with others," and "to be part of a group") all point to the notion that music is not likely used for purposes of social communion. These findings highlight an emblematic shift in how students are using music. It appears that listening to music is now a more solitary activity. For earlier generations, music was to be shared. Technology was limited to records and tapes, which made it difficult for individual consumption. With the advent of digital technology, music can travel anywhere and anytime over satellites and into computers and cell phones. Moreover, it can be listened to through a range of hightech speakers, headphones, and/or previously unimaginable ear "buds". Thus, music is much less likely to be used for social communion.

In summary, this research contributes to the study of music in education in three ways. First, it is the foundational investigation of music consumption amongst first-generation college students. We believe that better understanding the important role music plays in the lives of first-generation students (and college students collectively speaking) furthers student growth in and out of the classroom. Second, the findings here would seem to indicate that music is frequently used as a coping mechanism amongst first-generation college. It seems that while usage rates across groups are often quite similar, the reasons for using music during college are quite different. First-generation students appear to use music to deal with issues of loneliness, isolation, and the stresses that accompany university education. Third, for first-generation students, music is a crucial "instrument" which they quite frequently employ to facilitate, structure, and shape their personal and academic experiences. 


\title{
LIMITATIONS AND FUTURE RESEARCH
}

\author{
If everything was perfect, you would never learn and you would never grow. \\ Beyoncé (Hodges \& Bracco, 2001)
}

This study had limitations that should be addressed in future research. One of the main limitations this study faces is that the sample of first-generation college students is from a Western U.S. university that is designated as a Hispanic-Serving Institution. Hence, the results of this study may not embody the music consumption patterns or study behaviors of other college students across first-generation college students around the U.S (or the globe for that matter). Furthermore, these samples of students may not have revealed externally valid information about the music consumption patterns or study behaviors of students at private or larger universities. Also, the overall samples of African-American/Black students in both Study One and Study Two are relatively small in this paper and may not be generalizable to other U.S. colleges. This limitation is concerning because prior evidence by Coffman (2011) indicates that first-generation status has unique repercussions for college students' success, contingent on students' racial background. Future studies would be more valuable if they included a larger, more racially diverse sample of students thereby allowing for richer, more generalizable findings.

Another limitation of this study was that we failed to control for the work and commuting habits of the sample of students that participated in this study. Work/work-study obligations likely limit the availability of study time for both first and non-first-generation students. Alternatively, students that commute may have different demands placed on them compared those students that reside on campus. Recent evidence indicates that commuting students perform better academically than residential university students (Nonis \& Hudson, 2010). Overall, trade-offs inflicted by work and commuting-time commitments could have affected academic performance and study behavior.

Lastly, self-reported GPAs are apt to be subject to error and bias, which may denote constructirrelevance variance (Kuncel, Credé \& Thomas, 2015). Instead, future research should contemplate using university GPAs to provide a more objective and accurate measure. Measures of academic performance could be expanded to consider students' major GPA, credits earned, or differentiate between cumulative GPA and most recent semester GPA.

Regardless of this study's flaws, the work expands knowledge in the realm of education and firstgeneration status. Music usage in education is widespread and inclusive across student groups. Future research should strive to further illuminate motivating factors, it should investigate a wider range of individual difference variables, and it should more deeply delve into psychological processes. The current study sets the groundwork by revealing music as an intriguing new educational element worthy of future research.

\section{REFERENCES}

Anthony, A. (2008, April 19). The Boss picks his voice of America. The Guardian, Observer Music Profile. Retrieved November 7, 2020, from https://www.theguardian.com/music/2008/apr/20/uselections2008.springsteen

Borghans, L., Duckworth, A.L., Heckman, J.J., \& Ter Weel, B. (2008). The economics and psychology of personality traits. Journal of Human Resources, 43(4), 972-1059.

Braxton, J.M., Milem, J.F., \& Sullivan, A.S. (2000). The influence of active learning on the college student departure process: Toward a revision of Tinto's theory. The Journal of Higher Education, $71(5), 569-590$.

Bronfenbrenner, U. (1979). The Ecology of Human Development. Harvard University Press.

Carpentier, F.D., Knobloch, S., \& Zillmann, D. (2003). Rock, rap, and rebellion: Comparisons of traits predicting selective exposure to defiant music. Personality and Individual Differences, 35(7), $1643-1655$. 
Cataldi, E.F., Bennett, C.T., \& Chen, X. (2018). First-Generation Students: College Access, Persistence, and Postbachelor's Outcomes. Stats in Brief. NCES 2018-421. National Center for Education Statistics.

Chemers, M.M., Hu, L.T., \& Garcia, B.F. (2001). Academic self-efficacy and first year college student performance and adjustment. Journal of Educational Psychology, 93(1), 55.

Coffman, D. (2009). Questionnaire of new horizons international music association musicians. International Journal of Community Music, 1(3), 375-390.

Coffman, S. (2011). A social constructionist view of issues confronting first-generation college students. New Directions for Teaching and Learning, 2011(127), 81-90.

Coryn, C.L.S., Spybrook, J.K., Evergreen, S.D.H., \& Blinkiewicz, M. (2009). Development and evaluation of the social-emotional learning scale. Journal of Psychoeducational Assessment, 27(4), 283-295. doi:10.1177/0734282908328619

Crutchfield, R., \& Maguire, J. (2018). Study of student basic needs. California State University Basic Needs Initiative. Retrieved from https:/www2. calstate. edu/impact-of-the- csu/studentsuccess/basicneeds-initiative/Documents/phaseII-report-with-Appendix.pdf

Degand, D. (2013). A phenomenological multi-case study about social success skills, aspirations, and related media experiences. The Qualitative Report, 20(6), 872-900.

Drago, F. (2011). Self-esteem and earnings. Journal of Economic Psychology, 32(3), 480-488.

Dylan, B. (1964). The times they are a-changin. [Recorded by Bob Dylan]. On The times they are achangin [CD]. New York, USA: Columbia Studios.

Elias, M.J. (2006). The connection between academic and social-emotional learning. The educator's guide to emotional intelligence and academic achievement, pp. 4-14.

Ellis, R.A., \& Taylor, M.S. (1983). Role of self-esteem within the job search process. Journal of Applied Psychology, 68(4), 632.

Fenty, R. (2007). Good Girl Gone Bad. Def Jam Recordings and SRP Records.

Freeman, W. (2001). A neurobiological role of music in social bonding. In N.L. Wallin, B. Merker, \& S. Brown (Eds.), The origin of music (pp. 411-423). Cambridge, MA: MIT Press.

Gabrielson, A. \& Juslin, P. (1996). Emotional expression in music performance: Between the performer's intention and the listener's experience. Psychology of Music, 24, 68-91.

Gurgen, E.T. (2016). Social and emotional function of music listening: Reasons for listening to Music. Eurasian Journal of Educational Research, 66, 229-242.

Hargreaves, D.J., \& North, A.C. (1999). The functions of music in everyday life: Redefining the social in music psychology. Psychology of Music, 27(1), 71-83.

Hart Research Associates (HART). (2018). Fulfilling the American dream: Liberal education and the future of work: Selected findings from online surveys of business executives and hiring managers. Retrieved from https://www.aacu.org/sites/default/files/files/LEAP/2018EmployerResearchReport.pdf

Heckman, J.J., Stixrud, J., \& Urzua, S. (2006). The effects of cognitive and noncognitive abilities on labor market outcomes and social behavior. Journal of Labor Economics, 24(3), 411-482.

Herbert, R. (2012). Young people's use and subjective experience of music outside school. Proceedings of the 12th International Conference on Music Perception and Cognition, pp. 424-431. Thessaloniki, Greece.

Higham, T., Basell, L., Jacobi, R., Wood, R., Ramsey, C.B., \& Conard, N.J. (2012). Testing models for the beginnings of the Aurignacian and the advent of figurative art and music: The radiocarbon chronology of Geißenklösterle. Journal of Human Evolution, 62(6), 664-676.

Hodges, S., \& Bracco, L. (2013). New again: Destiny's child. Interview. Retrieved from https://www.interviewmagazine.com/music/new-again-destinys-child

Hoyle, R.H., \& Crawford, A.M. (1994). Use of individual-level data to investigate group phenomena issues and strategies. Small Group Research, 25(4), 464-485.

Ippolito, L.M., \& Adler, N.J. (2018, April). Shifting metaphors, shifting mindsets: Using Music to change the key of conflict. Journal of Business Research, 85, 358-364 
Jenkins, S.R., Belanger, A., Connally, M.L., Boals, A., \& Durón, K.M. (2013). First-generation undergraduate students' social support, depression, and life satisfaction. Journal of College Counseling, 16(2), 129-142.

Juslin, P.N., Liljeström, S., Västfjäll, D., Barradas, G., \& Silva, A. (2008). An experience sampling study of emotional reactions to music: Listener, music, and situation. Emotion, 8(5), 668.

Kokotsaki, D., \& Hallam, S. (2007). Higher education music students' perceptions of the benefits of participative music making. Music Education Research, 9(1), 93-109.

Kuh, G.D. (1995). The other curriculum: Out-of-class experiences associated with student learning and personal development. The Journal of Higher Education, 66(2), 123-155.

Kuncel, N.R., Credé, M., \& Thomas, L.L. (2005). The validity of self-reported grade point averages, class ranks, and test scores: A meta-analysis and review of the literature. Review of Educational Research, 75(1), 63-82.

Lamont, A., Hargreaves, D.J., Marshall, N.A., \& Tarrant, M. (2003). Young people's music in and out of school. British Journal of Music Education, 20, 229-241.

Manturszewska, M., Miklaszewski, K., \& Biatkowski, A. (1995). Psychology of music today. Warsaw: Fryderyk Chopin Academy of Music.

Marley, R.N. (1975). Lyrics from "Trenchtown Rock" published by Island Records.

Matsunobu, K. (2011). Spirituality as a universal experience of music: A case study of North Americans' approaches to Japanese music. Journal of Research in Music Education, 59(3), 273-289.

McCarron, G.P., \& Inkelas, K.K. (2006). The gap between educational aspirations and attainment for first-generation college students and the role of parental involvement. Journal of College Student Development, 47(5), 534-549.

McCormick, N. (2012, June 16). Tom Petty: A rock star for the ages. The Telegraph.

Mehr, S.A., Kotler, J., Haig, D., \& Krasnow, M.M. (2017). Genomic imprinting is implicated in the psychology of music. Psychological Science, 28(10), 1455-1467.

Melzer, D.K., \& Grant, R.M. (2016). Investigating differences in personality traits and academic needs among prepared and underprepared first-year college students. Journal of College Student Development, 57(1), 99-103.

Merriam, A.P., \& Merriam, V. (1964). The anthropology of music. Northwestern University Press.

Nonis, S.A., \& Hudson, G.I. (2010). Performance of college students: Impact of study time and study habits. Journal of Education for Business, 85(4), 229-238.

North, A.C., Hargreaves, D.J., \& Hargreaves, J.J. (2004). Uses of music in everyday life. Music Perception: An Interdisciplinary Journal, 22(1), 41-77.

North, A.C., Hargreaves, D.J., \& O'Neill, S.A. (2000). The importance of music to adolescents. British Journal of Educational Psychology, 70(2), 255-272.

Pascarella, E.T., Pierson, C.T., Wolniak, G.C., \& Terenzini, P.T. (2004). First-generation college students: Additional evidence on college experiences and outcomes. The Journal of Higher Education, 75(3), 249-284.

Peacock, K., \& Sydral, K. (2021). Quotes to make you smile. Quote Catalog. Retrieved from https://quotecatalog.com/quotes/quotes-to-make-you-smile

Rendón, L.I. (1994). Validating culturally diverse students: Toward a new model of learning and student development. Innovative Higher Education, 19(1), 33-52.

Rentfrow, P.J., \& Gosling, S.D. (2003). The do re mi's of everyday life: The structure and personality correlates of music preferences. Journal of Personality and Social Psychology, 84(6), 1236-1256.

Robinson, K. (2001). All our futures: Creativity, culture and education. Sudbury: DfEE.

Saarikallio, S., \& Erkkilä, J. (2007). The role of music in adolescents' mood regulation. Psychology of Music, 35(1), 88-109.

Schäfer, T., Smukalla, M., \& Oelke, S. (2013). How music changes our lives: A qualitative study of the long-term effects of intense musical experiences. Psychology of Music, 0, 1-20.

Schruers, F. (2014). Billy Joel: The Definitive Biography. New York, NY: Crown Archetype. 
Serrano, C.E. (2015). Skalifornia: Identity resistance and empowerment in the Chicana/o Latina/o Ska (core) music scene in Los Angeles. The University of Texas at San Antonio.

Statista. (2020). Number of on-demand music streams in the United States from 2013 to 2020 (in billions). Retrieved September 12, 2020, from https://www.statista.com/statistics/384687/on-demandmusic-streams-number-usa/

Tarrant, M., North, A.C., \& Hargreaves, D.J. (2000). English and American adolescents' reasons for listening to music. Psychology of Music, 28(2), 166-173.

Tekman, H.G., \& Hortac S.N. (2002). Aspects of stylistic knowledge: What are different styles like and why do we listen to them? Psychology of Music, 30, 28-47.

Tinto, V. (1987). Leaving college: Rethinking the causes and cures of student attrition. Chicago, IL: University of Chicago Press.

U.S. Department of Education (USDoE). (1998). National Center for Education Statistics. Firstgeneration students: Undergraduates whose parents never enrolled in postsecondary Education, NCES 98-082. Retrieved from https://nces.ed.gov/pubs98/98082.pdf

University of California (UC). (2017). First-generation student success at the University of California. Retrieved from https://www.ucop.edu/institutional-research-academicplanning/_files/first-generation-student-success-at-UC.pdf

US Music Festival. (1983). Video interview. Retrieved November 13, 2020, from https://www.youtube.com/watch?v=ZAg-AZDTxqA

Walker, R. (1996). Open peer commentary: Can we understand the music of another culture? Psychology of Music, 24(2), 103-114.

Wang, N., Wilhite, S.C., Wyatt, J., Young, T., Bloemker, G., \& Wilhite, E. (2012). Impact of a college freshman social and emotional learning curriculum on student learning outcomes: An exploratory study. Journal of University Teaching and Learning Practice, 9(2), 8.

Ward, L., Siegel, M., \& Davenport, Z. (2012). First-Generation college students: Understanding and improving the experience from recruitment to commencement. San Francisco, CA: John Wiley \& Sons.

Wyatt, J.B., \& Bloemker, G.A. (2013). Social and emotional learning in a freshman seminar. Higher Education Studies, 3(1), 106-114.

Zillmann, D., Gan, S.L., Hargreaves, D.J., \& North, A.C. (1997). The social psychology of music.

Zwerling, L.S., \& London, H.B. (1992). First-Generation Students: Confronting the Cultural Issues. New Directions for Community Colleges, Number 80. Jossey-Bass, Inc., Publishers, San Francisco, CA. 